\title{
RENAL MORPHOMETRY OF FETUSES RATS TREATED WITH CADMIUM
}

\author{
MORFOMETRÍA RENAL DE FETOS DE RATA TRATADOS CON CADMIO
}

${ }^{*}$ T. R. N. Roman; ${ }^{* *}$ E. G. de Lima; ${ }^{* *}$ R. Azoubel \& **F. Batigália

ROMAN, T. R. N.; DE LIMA, E. G.; AZOUBEL, R. \& BATIGÁLIA, F. Renal morphometry of fetuses teated with cadmium. Int. J. Morphol., 22(3):231-236, 2004.

SUMMARY: Cadmium is a heavy metal which is found in the soil, air and food. It is present in everyday life and currently it is being implicated as a toxic, teratogenic and carcinogenic agent. It causes lesions to several organs of humans and animals alike.

This work aims to investigate the toxic effects on fetuses of dams exposed to cadmium chloride treatment. Ten pregnant rats were divided into two groups. Five rats, the study group, received an intraperitoneal administration of cadmium chloride at $5 \mathrm{mg} / \mathrm{Kg}$ body weight on the 10th day of pregnancy and the other five, the study group, received a solution of $0.85 \%$ sodium chloride at the same dose and at the same application site.

The fetuses together with the placentas and umbilical cords were collected on the 20th day of pregnancy. The administration of cadmium chloride caused a significant reduction in the sizes of both the fetuses and the placenta. The lengths of the umbilical cords were also shorter in animals of the study group when compared with the control group.

This study also evaluated the morphological alterations caused in the proximal and distal convoluted renal tubules and collectors as well as the renal glomerular cells. Morphometry evidenced significant alterations in the proximal tubules and the glomerular cells and to a lesser degree in the distal tubules. The brush-border membrane cells were seen to be very sensitive and displayed some alterations. The glomeruli presented with edema and the Bowman's capsules were also affected.

KEY WORDS: 1. Cadmium; 2. Nephrotoxicity; 3. Karyometry.

\section{INTRODUCTION}

Cadmium exists in low concentrations in the earth's crust (Friberg et al., 1974; Bernard \& Lauwerys, 1984; Departament of Health and Human Services, 1992 and Pinot et al., 2000) and is generally associated with zinc, as a sulfite deposit. It is a malleable, soft, ductile, light silver-colored metal. It does not possess any essential function in the organism (Friberg et al.; Pinot et al.; Bernard et al., 1979 and Swiergosz 2001) of any living system, but there is much evidence of its toxic effects. It can cause acute intoxication (Friberg et al.; Bernard \& Lauwerys; Departament of Health and Human Services; Swiergosz and Roels et al., 1981) in workers directly exposed in their workplaces (Friberg et al.; Bernard \& Lauwerys and Departament of Health and Human Services) and in populations in industrially polluted areas (Friberg et al.; Bernard \& Lauwerys; Pinot et al. and Roels et al.). The anthropogenic sources are less innocuous than those resulting from the industrial production of batteries, (Adams et al., 1969) plastics, synthetic materials and alloys. It is re-encountered in the environment in the form of atmospheric emissions, (Demuynck et al., 1976 and EPA-US 1991) liquid effluents and in liquid and solid forms of sewerage (Pinot et al.).

The use of phosphate fertilizers has had a great effect on the concentration of cadmium in the soil (Kumar et al., 2000).

Cigarettes are an important source of exposure (Lewis et al., 1972; Elinder et al., 1976 and Piscator et al., 1976). Smokers are subjected to a greater exposure compared to non-smokers and this is reflected in elevated levels of cadmium by the human body (World 1992; Kido, 1995; ATSDR, 1999 and Ohta \& Cherian 1991) it is slowly eliminated. In the kidney, this time interval is expressed in

* Faculdade de Medicina de São José do Rio Preto and Faculdade de Medicina de Catanduva, Brasil
** Faculdade de Medicina de São José do Rio Preto, Brasil. 
decades (Friberg et al. and Pinot et al.). This results in a continuous increase over the years in the body load, even in cases of low exposure and absorption levels (Friberg et $a l$; ; Bernar \& Lauwerys and Pinot et al.).

On being absorbed it is transported to the liver and it stimulates the synthesis of methallotionein in the hepatocytes (Ohta \& Cherian; Cherian \& Shaikh, 1975 and Nordberg, 1978).

After oral or parenteral exposure or by inhalation in high concentrations, cadmium causes the formation of methallotionein in the liver (Cherian \& Shaikh and Nordberg). This organ controls the release of cadmium to other tissues (Stohs et al.). Induction of methallotionein and the possibility of the production of other proteins, protect the structure of these cells from toxicity (Nordberg; Stohs et al.; Sato \& Kondoh, 2002 and Squibb et al., 1979). This induction is considered to be dependent on the balance between the new synthesis of methallotionein in the renal tubule cells and the release of cadmium ions from lysosomal cadmium-methallotionein removed from the tubular fluid (Stohs et al.; Squibb et al. and Squibb \& Fowler, 1984).

The concentration of urinal cadmium is a useful indicator of exposure both in the workplace and environment as an increase in excretion in the urine is detected when renal tubular dysfunction occurs (Bernard \& Hermans, 1997).

The aim of this work is to evaluate toxicity on fetal kidneys of rats caused by the administration of cadmium. This was achieved by performing an experimental study on rats to determine, utilizing karyometry, morphometric alterations induced in the proximal and distal convoluted tubules, the collector tubules and the glomeruli of kidneys of fetuses by treating pregnant dams with a single dose of cadmium chloride.

\section{MATERIAL AND METHOD}

Ten female and two male rats (Rattus norvergicus albinus, variety Wistar) were used and divided into two groups of five female and one male for breeding purposes. The virgin rats, on being selected, weighed an average of 227 grams and reached a mean weight of 330 grams on the 20th day of pregnancy, exactly at the moment preceding sacrifice.

Treatment with cadmium. The treatment of the rats occurred on the tenth day of pregnancy when a single inoculation was administered in the abdominal cavity of each female as follows:

Control group: injection of 1 milliliter of $0.85 \%$ sodium chloride solution

Treated group: injection of an aqueous cadmium chloride solution containing 5 milligrams per kilogram of body weight.

The pregnant dams were sacrificed after being duly anesthetized. A broad incision in the abdomen and uterus was necessary to expose the fetuses.

Histological procedures obeyed general. The nuclei were projected on paper and, taking care to only include elliptic cells, their outlines were traced using a black pencil. Subsequently, the greater and smaller axes of the nuclear images were measured using millimetered graph paper. The results were input in to the NUC computer program, elaborated by Dr. Geraldo Maia Campos from the Department of Odontology, University of São Paulo in Ribeirão Preto.

The following parameters were measured:

Greatest diameter (D), smallest diameter (d), mean diameter (MD), the ratio of the greatest and smallest diameters $(\mathrm{D} / \mathrm{d})$, volume $(\mathrm{V})$, area $(\mathrm{A})$, perimeter $(\mathrm{P})$, the ratio of the volume and area (V/A), eccentricity $(\mathrm{E})$, the shape coefficient (SC) and contour index (CI) (Sala et al., 1980 and Gousset, 1908).

The diameters and the perimeters were measured in micrometers $(\mu \mathrm{m})$, the volumes in cubic micrometers $\left(\mu \mathrm{m}^{3}\right)$ and the areas in square micrometers $\left(\mu \mathrm{m}^{2}\right)$.

The glomeruli were drawn in a similar manner to the nuclei of the renal tubules. The greatest and smallest diameters of the nuclei of both the Bowman's capsule and the glomeruli themselves were calculated.

Non-matched student t-test (Foulkes, 1978) was used to compare the morphological and karyometric parameters obtained in the two groups. The student t-test was applied using the Graph InStat computer program version 3.00 for Windows 95, San Diego California, USA. With this program the mean, median, standard deviation (SD), mean standard error (MSE) values of the superior and inferior confidence intervals (95\%) the minimum and maximum values of the sample and the $\mathrm{p}$ - and t-values for each of the analyzed karyometric parameters were identified. 


\section{RESULTS}

Morphological results. Table I demonstrates the mean results obtained using karyometry on the renal structures considered in the experiment.
The obtained means of the glomerular volumes were $46,076.86 \mu \mathrm{m}^{3}$ in the control group and $65,777.64 \mu \mathrm{m}^{3}$ in the treated group, giving a p-value of 0.0007 considered statistically significant $(<0.05)$. In respect to the Bowman's capsule, the mean values were $101,836.90 \mu^{3}$ in the control group and $145,824.35 \mu^{3}$ in the treated group, giving a $\mathrm{p}$-value $=0.0015$ also considered statistically significant.

Table I: Mean greatest and smallest diameters, mean tubule diameter, greatest/smallest diameter ratio, volume, area, perimeter, volume/ area ratio, eccentricity, shape coefficient and contour index of the nuclei of collector tubules and proximal and distal convoluted tubules of the fetal kidneys of the dams from the control and treated groups.

\begin{tabular}{lcrrrrr}
\hline & \multicolumn{2}{c}{ Collector tubules } & \multicolumn{2}{c}{ Proximal tubules } & \multicolumn{2}{c}{ Distal tubules } \\
& Control & Treated & Control & Treated & Control & Treated \\
Greatest nuclear diameter $(\mu \mathrm{m})$ & 12.81 & 13.59 & 12.17 & 13.08 & 12.30 & 12.96 \\
Smallest nuclear diameter $(\mu \mathrm{m})$ & 9.88 & 9.95 & 10.46 & 10.27 & 9.64 & 9.32 \\
Mean tubular diameter $(\mu \mathrm{m})$ & 11.23 & 11.60 & 11.27 & 11.57 & 10.85 & 10.90 \\
Greatest/smallest diameter ratio & 1.31 & 1.38 & 1.17 & 1.29 & 1.29 & 1.41 \\
Nuclear volume $\mu \mathrm{m}^{3}$ & 663.45 & 721.51 & 717.02 & 738.20 & 617.30 & 609.26 \\
Nuclear area $\mu \mathrm{m}^{2}$ & 99.76 & 106.71 & 100.74 & 106.01 & 93.62 & 95.49 \\
Nuclear perimeter $\mu \mathrm{m}$ & 37.94 & 39.85 & 36.90 & 38.92 & 36.55 & 37.84 \\
Volume/area ratio & 6.59 & 6.64 & 6.97 & 6.85 & 6.43 & 6.21 \\
Eccentricity & 0.60 & 0.65 & 0.46 & 0.58 & 0.58 & 0.66 \\
Nuclear shape coefficient & 0.87 & 0.84 & 0.92 & 0.88 & 0.88 & 0.83 \\
Contour index & 3.81 & 3.88 & 3.70 & 3.80 & 3.80 & 3.90 \\
\hline
\end{tabular}

\section{DISCUSSION}

Nephrotoxicity. The treatment with parenteral $\mathrm{CdCl}^{2}$ in rats diminishes the mean glomerular filtration with a reduction in the filtration fraction. Moreover, continued exposure results in progressive sclerosis of $t$ exposure at low levels or by oral exposure.

During chronic exposure, cadmium-metallothionein is liberated by the liver and transported to the kidneys (World Health Organization; Cherian \& Shaikh; Nordberg). This complex if filtered by the glomeruli and reabsorbed by the cells of the proximal tubules by the transport mechanism of low-weight molecular proteins (Kido; Cherian \& Shaikh; Nordberg and Foulkes). After entering into the lysosome, it undergoes stimulates the synthesis of more metalloprotein in the tubule cells and becomes linked to it (Cherian \& Shaikh; Nordberg and Foulkes) but the intercellular metal, not bound to metallothionein, increases when its concentration exceeds the capacity of the proximal tubular cells to synthesize metallothionein (Shaikh, 1982). The low molecular weight allows the protein to be filtered through the glomerular filter and thus to be absorbed by the tubular liquid in the renal cells. This mechanism might explain the selective accumulation of cadmium in the renal cortex (Friberg et al.).
An increased excretion of cadmium in the urine in individuals with renal disease is caused by tubular reabsorption cadmium-metallothionein complex (Cherian \& Goyer, 1976; Rodriguez-Barbero et al., 2000; Stinson et al. 2003). Proximal tubular dysfunction in mammals, due to nephrotoxicity caused by cadmium, results in a reduced functional capacity of the brush-border membrane (Ahn Whan et al., 1999; Sabolic et al., 2002). This damage is caused by diverse factors: 1) by direct inhibition by cadmium of the brush-border transporters; 2) by the shortening and reduced numbers of the microvilosities and 3 ) by the loss of specific brush-border transporters (Ahn Whan et al.).

The proximal tubules present with alterations in the greatest diameter $(\mathrm{p}$-value $=0.0185)$, in the ratio between the greatest and smallest diameters ( $p$-value $=0.0002$ ), eccentricity ( $\mathrm{p}$-value $<0.0001$ ), the nuclear shape coefficient $(p$-value $=0.0001)$, the contour indexes $(p$-value $=0.0002)$. All of these were considered statistically significant. The value for eccentricity of the collector (p-value 0.092) and distal ( $p$-value $=0.006$ ) tubules were respectively considered not significant and significant.

The following values for the collector tubules were considered to be statistically significant: greatest diameters ( $\mathrm{p}$-value $=0.0392)$; the greatest $/$ smallest diameter ratio $(\mathrm{p}$ - 
value $=0.0307)$; nuclear contour index $(p$-value $=0.033)$; and the shape coefficient ( $\mathrm{p}$-value $=0.045)$. For the distal tubules the following data were considered statistically significant: greatest diameters $(\mathrm{p}$-value $=0.043)$ the greatest $/$ smallest diameter ratio ( $\mathrm{p}$-value $=0.0067$ ); eccentricity ( $\mathrm{p}$-value $=0.006)$; nuclear contour index $(\mathrm{p}$-value $=0.009)$; and the shape coefficient ( $\mathrm{p}$-value $=0.008$ ).
These findings demonstrate evidence of alterations in the shape with a tendency to rounding of the nuclei.

In relation to the glomeruli, (Jarup et al., 1995) when tubular damage occurs owing to cadmium, this leads to irreversible proteinuria and continuous exposure can cause glomerular damage with a reduction in the average filtration, even a long time after the end of exposure (Jarup et al.).

ROMAN, T. R. N.; DE LIMA, E. G.; AZOUBEL, R. \& BATIGÁLIA, F. Morfometría renal de fetos de rata tratados con cadmio. Int. J. Morphol., 22(3):231-236, 2004.

RESUMEN: El cadmio es un metal pesado que se encuentra en la tierra, aire y alimentos. Está presente en forma coditiana todos los días de la vida y actualmente es catalogado como un tóxico, teratogénico y agente carcinogénico. El cadamio causa numerosas lesiones a los órganos humanos y animales.

Este trabajo tiene como objetivo investigar los efectos tóxicos en fetos de ratas expuestas a tratamiento con cloruro de cadmio. 10 ratas preñadas fueron divididas en dos grupos. Cinco ratas recibieron por administración intraperitoneal $5 \mathrm{mg} / \mathrm{Kg}$ de cloruro de cadmio por peso corporal, durante 10 días de preñez y otras cinco ratas recibieron bajo las mismas condiciones del otro grupo, una solución de cloruro de sodio al $0.85 \%$.

Los fetos fueron extraídos junto con las placentas y funículos umbilicales a los 20 días de preñez. La administración del cloruro de cadmio causó una reducción significativa en los pesos de los fetos y placentas. La longitud del funículo umbilical fue más corta en el grupo experimental que en el grupo control.

El estudio evaluó las alteraciones morfológicas causadas en los túbulos proximal, distal, contorneados y colectores renales como también en las células del glomérulo renal. La morfometría evidenció alteraciones significativas en los túbulos proximales y en las células glomerulares y, en menor grado, en los túbulos distales. El borde en cepillo de la membrana celular se observó muy sensible y se visualizaron algunas alteraciones. Los glomérulos se presentaron con edema y la cápsula del glomérulo fue también afectada.

PALABRAS CLAVE: 1. Cadmio; 2. Nefrotoxicidad; 3. Cariometría.

\section{REFERENCES}

Adams, R. G.; Harrison, J. F. \& Scott, P. The development of cadmium-induced proteinuria, impaired renal function, and osteomalacia in alkaline battery workers. Q. J. Med., 38:239-43, 1969.

Ahn Whan, Kim, Y. M.; Kim, K. R. \& Park, Y.S. Cadmium binding and sodium-dependent solute transport in renal brush-border membrane vesicles. Toxicol. Appl. Pharmacol., 154:212-8,1999.

ATSDR-Agency for Toxic Substances and Disease Registry. Toxicological Profile or cadmium. Atlanta, GA: US Department of Health and Human Services, Public Health Service, 1999.

Bernard, A.; Buchet, J. P.; Roels, H.; Masson, P. \& Lauwerys, R. Renal excretion of proteins and enzymes in workers exposed to cadmium. Eur. J. Clin. Invest., 9:11-22, 1979.
Bernard, A.; Hermans, C. Biomonitoring of early effects on the kidney or the lung. Sci Total Environ., 199: 205$11,1997$.

Bernard, A. \& Lauwerys, R. Cadmium in human population. Experientia, 40(2):143-52, 1984.

Cherian, M. G. \& Goyer, R.A.; Delaquerriere-Richardson, L. Cadmium metallothionein induced nephropathy. Toxicol. Appl. Pharmacol., 38: 399-408,1976.

Cherian, M.G.; Shaikh, Z.A. Metabolism of intravenously injected cadmium-binding protein. Biochem. Biophys. Res. Commun., 65: 863-9, 1975.

Demuynck, M.; Rahn, K.A.; Janssens, M. \& Dams, R. Chemical analysis of airborne particulate matter during a period of usually high pollution. Atms. Environ., 10:21, 1976. 
Department of Health and Human Services (USA). Occupational Exposure to Cadmium. Final Rules, 1992.

Elinder, C. G.; Kjellström, T.; Friberg. L.; Lind, B. \& Linnman, L. Cadmium in kidney cortex, liver, and pancreas from Swedish autopsies. Arch. Environ. Health., 31:292, 1976.

EPA-US Environmental Protection Agency 1001. Cadmium in drinking water. Federal Register, 56:3526, 1991.

Foulkes, E.C. Renal tubular transport of cadmiummetallothionein. Toxicol. Appl. Pharmacol., 45:505-12, 1978.

Friberg, L.; Piscator, M.; Nordberg, G. F. \& Kjellström, T. Cadmium in the Environment. 2. ed. Cleveland: CRC Press, 1974.

Gousset, W. S. The probable error of a mean. Biometrika, 6:1-25, 1908.

Harkema, J. R. Morphometric methods for studying airway cell density/Proliferation. American Thoracic Society. American Lung Association. San Francisco, CA. Posgraduate Course 3; 1997.

Hassler, E.; Lind, B.; Piscator, M. Cadmium in blood and urine related to present and past exposure. A study of workers in an alkaline battery factory. Br. J. Ind. Med., 40:420-5, 1983.

Herawati, N.; Suzuki, S.; Hayashi, K.; Rivai, I. F.; Koyama, H. Cadmium, copper, and zinc levels in rice soil of Japan, Indonesia and Chine by soil typo. Bull. Environ. Contam. Toxicol., 64(1):39-49, 2000.

Jarup, L.; Oersson, B.; Elinder, C.G. Decreased glomerular filtration rate, in solderers exposed to cadmium. Occup. Environ. Med., 52(12):818-22, 1995.

Kido T. Renal and bone effects. Environ Sci., 3:149-62, 1995.

Kumar, R.; Pant, N.; Srivasta, S. P. Chlorinated pesticides and heavy metals in human semen. TJ Androl., 23(3): $145-9,2000$.

Lewis, G. P.; Coughlin, L.; Jusko, W. \& Hartz, S. Contribution of cigarettes smoking to cadmium accumulation in man. Lancet., 1:291-2, 1972.

Nordberg, M. Studies on metallothionein and cadmium. Environ. Res., 15:381-404, 1978.
Ohta, H.; Cherian, M.G. Gastrointestinal absorption of cadmium and metallothionein. Toxicol., 107:63-72, 1991.

Pinot, F.; Kreps, S. E.; Bachelet, M.; Hainaut, P.; Bakonyi, M. \& Polla, B.S. Cadmium in the environment: sources, mechanisms of biotoxicity, and biomarkers. Res. Environ. Health., 15(3):299-323, 2000.

Piscator, M.; Kjellström, T. \& Lind, B. Contamination of cigarettes and pipe tobacco by cadmium- oxide dust. Lancet II, 587, 1976.

Rodriguez-Barbero, A.; L'Ázou, B.; Cambar, J. \& LopezNovoa, J.M. Potencial use of isolated glomeruli and cultured mesangial cells: in vitro models to assess nephrotoxicity. Cell. Biol. Toxicol., 16(3):145-53, 2000.

Roels, H. A.; Lauwerys, R. R.; Buchet, J. P. \& Bernard, A. Environmental exposure to cadmium and renal function of aged women in thre areas of Belgium. Environ. Res., 24:117-30, 1981.

Sabolic, I.; Ljubojevic, M.; Herak, K.C.M.; Brow, D. CdMT cause endocytosis of brush-border transporters in rat proximal tubules. Am. J. Physiol. Renal. Physiol., 283(6):1389-402, 2002.

Sakuma, A. M.; Scorsafava, M. A.; Zenebon, O.; Tiglea, P. \& Fukumoto, C. J. Hortaliças comercializadas em São Paulo: aspectos da contaminação por chumbo, cádmio e zinc. Rev. Inst. Adolfo Lutz, 49(1):81-4, 1989.

Sala, M. A.; Matheus, M.; Valeri, V. Estimation of the average diameter of human placental villi by a stereological method. Microsc. Acta, 82:339-42, 1980.

Sato, M. \& Kondoh, M. Recent studies on metallothionein: protection against toxicity of heavy metals and oxygen free radicals. Tohoku. J. Exp. Med., 196(1):9-22, 2002.

Shaikh, Z.A. Metallothionein as a storage of cadmium: its toxicological implications. Rev. Toxicol. Environ. Sci., 9:69-76, 1982.

Squibb, K. S. \& Fowler, B.A. Intracellular metabolism and effects of circulating cadmium metallothionein in the kidney. Environ Health Perspect., 54:31-5, 1984.

Squibb, K. S.; Ridlington, J. W.; Carmichael, N.G. \& Fowler, B. A. Early cellular effects of circulating cadmium-thionein on kidney proximal tubules. Environ Health Perspect., 28:287-96, 1979. 
Stinson, L.J.; Darmon, A.J.; Dagnino, L. \& D’Souza, S.J. Delayed apoptosis post-cadmium injury in renal proximal tubule ephitelial cells. Am. J. Nephrol., 23(1): 27-37, 2003.

Stohs, S. J.; Bagchi, D.; Hassoun, E. \& Bagchi, M. Oxidative mechanisms in the toxicity of chromium and cadmium ions. J. Environ. Pathol. Toxicol. Oncol., 20(2):77-88, 2001.

Swiergosz, K.R. Cadmium distribution and toxicity in tissues of small rodents. Microsc. Res. Tech., 55(3):208-22, 2001.

World Health Organization - Environmental Health Criteria 134. Cadmium. Geneva. World Health Organization 1280, 1992.
Correspondence to: Prof. Dr. T. R. N. Roman

Faculdade de Medicina de São gose do Rio Preto Pós-Graduação

Av. Brigadeiro Faria Lima, 5416

CEP: 15090-000

Universitário - São José do Rio Preto-SP

BRASIL

E-mail: rosedesiderio@famerp.6r

Received : 03-07-2004

Accepted: 12-08-2004 